\title{
ENTREPRENEURSHIP IN THE BUSINESS MARKET OF PETROLEUM PRODUCTS MARKETING
}

\author{
Liliana Doina MĂGDOIU ${ }^{1}$, Mircea Ioan GORDAN ${ }^{2}$, Helga SILAGHI ${ }^{1}$, Anca PĂCALĂ ${ }^{1}$ \\ ${ }^{1}$ Control Systems Engineering Department, University of Oradea, Str. Universităţii nr. 1, Oradea, Romania \\ E-mail: 1ili34ana@yahoo.com, hsilaghi@uoradea.ro, ancapacala19@gmail.com \\ ${ }^{2}$ Electrical Engineering Department, University of Oradea, Str. Universităţii nr. 1, Oradea, Romania \\ E-mail: mgordan@uoradea.ro,
}

\begin{abstract}
This paper presents how in the business market of oil products marketing, an entrepreneur should be constantly aware of the needs, policies and purchasing techniques of companies, for the precise purpose of understanding what quantity of oil/complementary oil products and liquefied petroleum gas (LPG) products he can sell. In addition, the entrepreneur must also take into account the sales aimed at individuals, which are done, in particular, through the fuel distribution stations or through the points of sale of LPG loads.

The business market in the field of selling petroleum products includes the totality of the companies that purchase petroleum products, complementary products and LPG loads. The purpose of such companies is to produce other goods and services that can be sold, rented or provided to others.
\end{abstract}

Keywords: online marketplace business market, entrepreneurship, petroleum products marketing, factors influencing the purchasing decision.

\section{INTRODUCTION}

The activity of for-profit companies (companies with a pecuniary purpose) is not limited to sales operations; they also buy raw materials, finished products, petroleum and complementary products, LPG loads, services, etc. In recent years, the number of companies has decreased, either due to their closure or due to the restriction of their activities, since the conditions in which economy operated were not the habitual ones [1-3].

The entrepreneur should be constantly aware the needs, resources, policies and purchasing techniques of companies, for the precise purpose of understanding what quantity of oil/complementary oil products and liquefied petroleum gas (LPG) products he/she can sell [4]. In addition, the entrepreneur must also take into account the sales aimed at individuals, which are done, in particular, through the fuel distribution stations or through the points of sale of LPG loads, but also through the sales sections:

- companies buy these products for different purposes: making profits, reducing costs, meeting employee needs, fulfilling obligations, etc :;

- the making of the purchase decision from the companies in the commercial sections belonging to the field of petroleum products trade involves the participation of a larger number of people, compared to the situation when the purchase process is done at the fuel distribution stations or at the points of sale of LPG loads.

- These participants are usually the different compartments that analyse the act of purchase;

- buyers must comply with the procurement policy, the limits and the requirements set by the company to which they belong;

- $\quad$ specific purchasing instruments (requests for quotation, proposals, purchase contracts) represent a specific tool for business markets.

The purchasing process can be defined as "the decisionmaking process for the purchase of petroleum products, complementary products and LPG loads, necessary for a company, as well as their evaluation and choice from the multitude of suppliers and brands".

Although no two companies have the same buying behaviour, the entrepreneur tries to identify those common elements of behaviour that allow them to develop appropriate marketing strategies [7].

\section{WHAT DOES THE BUSINESS MARKET INCLUDE?}

The business market consists of all companies and institutions that purchase petroleum products, complementary products and LPG loads, with the purpose of producing other goods and services that will be sold, rented or provided to others [5].

Example: in order to be able to deliver its transport services, a transport company buys petroleum products (diesel, gasoline, bulk oil, etc.) for the fleet it owns, and it sells its services to other production companies, which, in turn, sell products to distributors or retailers and thus extend the chain to the end user (the consumer market). Each component of this supply chain buys many other necessary goods and services. This explains why the dimensions of the business market are definitely more extended than those of the consumer market [6].

The features defining business markets contrast sharply with those of consumer markets:

- Smaller number of buyers. The number of transport or tourism companies is far more limited than the number of buyers in the 
consumer market (market comprising between tens of thousands and hundreds of thousands of car owners).

- Most purchases are made only by a few more important buyers (carriers, resellers, thermal power plants, agriculture), representing over $70 \%$ of sales.

- Close relationship between supplier and customer.

- Concentration of consumers in a specific place. Over $70 \%$ of companies are concentrated in cities, or in a few larger communes, in the form of agricultural associations. This concentration of for-profit companies contributes to the reduction of the marketing expenses of the commercial sections based in the perimeter of these localities. Marketers also need to keep track of the changes that are taking place in their business area.

- Derived request. Demand in the business market ultimately derives from the demand for consumer goods. The demand for petroleum products, decreases and increases. Because of this, marketers need to keep a close eye on trends in consumption.

- Inelastic demand. Price changes affect to a small extent the total demand for petroleum products on the business market. Carriers will not buy much less or much more if the price increases or decreases. This is due to the inelasticity of demand, which generally manifests itself in the short run.

- Fluctuating demand. The demand for petroleum products on the business market is more fluctuating than their demand on the consumer market. The changes create insecurity for sellers and cause marketers to diversify their products and launch into other markets, to avoid the unbalancing of sales.

- Professional buying techniques. This urges entrepreneurs to provide and work with a greater number of information relating to their own petroleum products, complementary products and LPG loads, but also regarding the products sold by their competitors.

- Several factors influence the buying process. In general, as compared to consumers' purchasing requests, a large number of people influence the purchasing decisions made by companies. As such, well-trained sales agents or sales teams carry out transactions and negotiate with wellprepared buyers. Despite the fact that advertising, sales promotion and publicity play an important role in the mix of sales promotion for petroleum products, complementary products and LPG loads, the main mode of sale, with the most appreciated results, is the personal sale.

of suppliers. Taking into account these aspects, in the new purchasing situations, the contractor must direct the information regarding the petroleum products,

\section{DECISIONS MADE BY COMPANIES WHO BUY PETROLEUM PRODUCTS}

Buyers who are present in the business market must make several decisions when making a purchase, their number depending on the type of purchase situation in which they find themselves [8].

There are three main purchasing situations, which are also generically called "purchasing classes":

- Direct repeated purchase - specific to the situation in which the supply department repeats orders on a routine basis. The suppliers of petroleum products included in "approved list" are concerned with maintaining the quality of their products and the services. Off-list suppliers try to offer something new or speculate to the buyer's dissatisfaction, so that he buys some of the products needed from them.

- Modified repeated purchase - this involves an increased number of decision-makers on both sides. Approved suppliers become anxious and try to protect themselves, while non-approved suppliers see a proposal for a "better offer" on this occasion.

- New task - the buyer purchases an oil product for the first time. The higher the risks and costs, the higher the number of participants in the decision-making, the greater the need for prior information and, implicitly, the longer the time to make a final decision. The entrepreneur will try to get in touch with as many decision makers as possible, giving them the necessary support and information.

The purchase, seen as a new task, takes place over several stages: information, interest, evaluation, testing and adaptation.

The fewest decisions will be taken in the case of repeated direct purchase and, in most cases, in the situation where the purchase is a new task.

Companies choose to get the oil product and transportation service from a contractor in the field of oil products marketing. This entrepreneur must be aware of this and assist the beneficiary with regard to stock and quality control to meet his/her needs. The contractor can also provide services in terms of plant maintenance, tank cleaning, repair and maintenance of stoves, etc. beneficiaries who are constantly sourced from it [7].

\section{PARTICIPANTS IN THE PROCESS OF PURCHASING PETROLEUM PRODUCTS}

Merchandisers have a great influence in situations of repeated direct and modified purchase. Typically, engineers greatly determine the choice of product components, and purchasing agents dominate the choice

complementary products and LPG loads, first of all, to the purchasing agents. The department for making the decision to buy products within companies is called the 
supply department. It comprises all the people and groups involved in the purchasing decision-making process, who pursue common goals and assume the risks arising from the decisions made. The purchasing centre is made up of all the members of the company who fulfil one of the six roles in making the purchasing decision: users, influencers, decision makers, approvers and buyers in the case of complex acquisitions, the category of buyers may also include directors from higher hierarchical levels who participate in negotiations.

The contractor must periodically review his assumptions regarding the role and influence of the various participants in making the purchase decision.

\section{THE PROCESS OF MAKING PURCHASING DECISIONS IN THE CASE OF COMPANIES}

Buyers in business market do not purchase petroleum products for own consumption or use. Instead, they use the mentioned products to make a profit, to reduce production costs or to fulfil a social or legal obligation.

Table 1. The main stages in the purchasing process for petroleum products reported to the main classical purchasing situation

\begin{tabular}{|c|c|c|c|}
\hline \multirow[b]{2}{*}{ PURCHASING STAGES } & \multicolumn{3}{|c|}{ PURCHASING CLASSES } \\
\hline & $\begin{array}{l}\text { New } \\
\text { task }\end{array}$ & $\begin{array}{l}\text { Modified } \\
\text { repeated } \\
\text { purchase }\end{array}$ & $\begin{array}{c}\text { Repeated } \\
\text { direct } \\
\text { purchase }\end{array}$ \\
\hline 1. Identifying the problem & Yes & Possible & No \\
\hline 2. Describing the need & Yes & Possible & No \\
\hline $\begin{array}{l}\text { 3. Characteristics of the } \\
\text { product }\end{array}$ & Yes & Yes & Yes \\
\hline 4. Searching for a supplier & Yes & Possible & No \\
\hline $\begin{array}{|lrr|}5 . & \text { Request for an } \\
\text { offer/quotation } & & \\
\end{array}$ & Yes & Possible & No \\
\hline 6. Choosing a supplier & Yes & Possible & No \\
\hline $\begin{array}{l}\text { 7.Way of executing the } \\
\text { order }\end{array}$ & Yes & Possible & No \\
\hline 8. Results analysing & Yes & Yes & Yes \\
\hline
\end{tabular}

Internally, most common situations that determine the identification of a problem are:

-the company creates some activities for which it needs petroleum products;

-failure of a machine, means of transport, requires the replacement of the petroleum product;

-oil products delivered by one supplier prove to be unsatisfactory, in which case the company turns to another supplier;

-the person responsible for the purchase notices the possibility of obtaining a lower price at a higher quality.

Externally, new ideas can come to the buyer, following the participation in an exhibition, seeing an advertisement or receiving a proposal from a sales agent who offers a better product or a more attractive price. The
The entrepreneur must therefore find out who are the main participants in the decision-making process, what are the decisions they influence, to what extent they influence the decisions and what evaluation criteria they use.

Sellers in the field of petroleum products marketing need to focus on people who play a key role in influencing the act of buying.

entrepreneur has the opportunity to stimulate the identification of problems through advertising, contacting potential customers, etc.

The next step is to establish the characteristics of the range of petroleum products, a task that is entrusted to a team to analyse the value of the product. Value analysis is a way of approaching the reduction of costs due to the use of a certain oil product in the activity.

The analysis of the value of the product can also be used by the entrepreneur as a tool for positioning on the market for an advantage. By being involved early in the analysis process, the entrepreneur considerably increases his chances of being the one chosen in the selection stage.

At this stage, buyers try to identify the most suitable suppliers to solve their problem. They can consult a series of brochures mentioning the suppliers of petroleum products, they can call other companies to get recommendations, they can follow the ads that appear in the media or they can participate in specialized exhibitions. Now buyers have a small list of approved suppliers.

For choosing their suppliers, companies will increasingly use specially developed programs. Marketers need to know this process and be able to deal with it in order to become the supplier of that company.

In table 2 there is an example of evaluating a supplier of petroleum products.

Table 2. Evaluating a supplier of petroleum products

\begin{tabular}{||c||c|c|c|c|c||}
\hline \hline \multirow{1}{*}{ ATRIBUTTE } & $\begin{array}{c}\text { Unaccep } \\
\text { table } \\
(0)\end{array}$ & $\begin{array}{c}\text { Weak } \\
(1)\end{array}$ & $\begin{array}{c}\text { Medium } \\
(2)\end{array}$ & $\begin{array}{c}\text { Good } \\
(3)\end{array}$ & $\begin{array}{c}\text { Excellent } \\
(4)\end{array}$ \\
\hline $\begin{array}{c}\text { Marketing } \\
\text { capacity }\end{array}$ & & & & & $X$ \\
\hline $\begin{array}{c}\text { Financial power } \\
\text { Quality of } \\
\text { products }\end{array}$ & & & & $X$ & \\
\hline $\begin{array}{c}\text { Safety of } \\
\text { delivery }\end{array}$ & & & $X$ & & \\
\hline Transport service & & & & $X$ & \\
\hline \hline \multicolumn{5}{|c|}{ Average score: $16: 5=3,2$} \\
\hline \multicolumn{5}{|c|}{ Total score: $4+3+4+2+3=16$} \\
\hline
\end{tabular}


Compared to the scores made by different suppliers, the buyer will choose the one that will have the optimal score.

Most companies prefer to work with multiple suppliers, to avoid being dependent on a single source of supply. The buyer negotiates with the supplier the final order of petroleum products, establishing the product assortments, quantities, delivery terms, product return conditions, guarantees, etc. This order may be materialized by a contract for the sale-purchase of petroleum products between the two parties.

In a standard contract the supplier assumes the obligation to supply the beneficiary according to needs and resources, for the agreed period and price conditions. These contracts contribute to reducing the number of sources of supply and implicitly to increasing the quantities of products purchased from one source. Relationships can be broken only if the beneficiary becomes, at some point, dissatisfied with the prices, quality of products or services of the supplier.

\section{CONCLUSIONS}

Many of the issues highlighted in the case of for-profit firms also apply to the procurement practices of petroleum products by non-profit companies and institutions.

The market of non-profit companies is made up of educational institutions, health institutions, dormitories, penitentiaries, etc. which provides goods and services to the population. The purchasing agent of such an institution must decide on the quality of the petroleum product the institution wants to buy and on the price. In this case, because the purchased product is used for heating, hot water production, food preparation, etc., the goal of the non-profit agent is not profit. The procuring agent must choose those suppliers of petroleum products who meet or exceed the minimum quality standard and who practice low prices. These institutions can benefit from sponsorships from different sources and can have different objectives: some are for profit, others are nonprofit institutions, and others are government institutions.

In the case of government organizations, the procurement process has certain characteristics. Governmental institutions require suppliers to prepare substantial documentation, but due to bureaucracy, suppliers become dissatisfied with unnecessary regulations, late decision-making, frequent changes in procurement staff and, finally yet importantly, lack of money to pay the ordered products. Another feature of this market is the organization of auctions, the suppliers submitting their bids, the winner being always the bidder with the lowest price. A third feature of this market is the fact that government organizations tend to favour domestic suppliers. In general, suppliers who have the status of government suppliers show little concern for marketing, because their sales are assured.

\section{REFERENCES}

[1] Kotler, Ph. 2000. Marketing Management: Millennium Edition, Tenth Edition by Philip Kotler, Published by arrangement with original publisher, Prince Hall, Inc., a Pearson Education Company.

[2] Măgdoiu LD and Rada IC (2018a). Economic Engineering Qualification of Economist Engineers. LAP LAMBERT Academic Publishing, Saarbrücken, Germany.

[3] Eric T.G. Wang, Pei-Hung Ju, James J. Jiang, Gary Klein,The effects of change control and management review on software flexibility and project performance, Information \& Management,Volume 45, Issue 7,2008,Pages 438-443,ISSN 0378-7206.

[4] Yin, R.K. 2005. Case Study Research. Design and Methods, Sage Publications, Thousand Oaks, London, New Delhi.

[5] SAS Diana, SILAGHI Helga, MESAROS A., NEAGU M., SPOIALA D., Marketing Online Using Change Request Management, The Scientific Bulletin of Electrical Engineering Faculty SBEEF, ISSN (Online) 2286-2455, Vol.21, issue 1/2021, pp.1-5,

[6] S.Dale, Helga Silaghi, D. Zmaranda, U. Rohde, Intelligent Design Environment for Second-Order Positioning Systems, International Journal of Computers Communications and Control, ISSN 1841-9836, Vol.10, No 1, WOS:000345261400004, 2015.

[7] Rada I.C., Silaghi M.A., Silaghi H., Coroiu, N., Popa, M., Producing, Testing And Introducing New Models of Induction Mechanisms on the Market, Proceedings Book, 11th International Conference on Microwave and High Frequency Heating, AMPERE 2007, pp. 364-367.

[8] Spoiala D., Silaghi Helga, Spoiala Viorica, Cacuci A., Erp System Invirtualized Production Environment, The Scientific Bulletin of Electrical Engineering Faculty, ISSN (Online) 2286-2455, 2017 